UDC 343.91-053.6

Dolzhenkov Oleksandr,

Doctor of Juridical Sciences, Full Professor, Professor at the Department, South Ukrainian K.D. Ushynsky National Pedagogical University, Odesa, Ukraine

Pluhatar Tetiana,

Candidate of Juridical Sciences, Senior Researcher, Academic Secretary of the Academic Council, State Research Institute MIA Ukraine, Kyiv, Ukraine ORCID ID 0000-0003-2082-5790

\title{
SPECIAL AND CRIMINOLOGICAL MEASURES FOR JUVENILE DELINQUENCY PREVENTION IN UKRAINE
}

Paper is devoted to the definition of special criminological measures for the prevention of crimes committed by minors.

The issue of prevention of juvenile crimes in Ukrainian criminology has always been given considerable attention; a significant number of monographs, articles, and a number of dissertations on the subject have been defended. Instead, the precautionary provisions in these studies are significantly fragmented, affecting specific fields or areas of activity.

Complex criminological and individual approaches to secondary school are offered. Substantial practical recommendations for the national legislation adopted to ensure effective and efficient resolution of the problem are done.

Keywords: student violence, physical violence, mental violence, criminological characteristics, prevention, special criminological measures, crimes committed by minors.

The following scientists have made a significant contribution to the study of juvenile delinquency: Y. Abrosimova, V. Afanasiev, O. Bandurka, I. Bogatyrev, V. Vasilevich, D. Vygovsky, V. Golina, A. Husak, N. Gradetska, O. Dzhuzha, T. Kalchenko, O. Kolb, S. Koretsky, N. Kuznetsova, I. Lubenets, N. Tuza, and other scientists. Instead, the precautionary measures in these studies are highlighted mostly fragmentely, referring to specific areas or spheres of mentioned activity. Our task was to formulate on the basis of the results of our own research, the studies of other authors, to generalize foreign experience and to formulate the most comprehensive, suitable for Ukraine and actual system of measures for the prevention of juvenile delinquency.

1. The list of subjects for the prevention of offenses among children in Ukraine is defined by the Law of Ukraine "On Bodies and Services for Children and Special Institutions for Children” dated January 24, 1995 [1]. They are currently classified as: the central executive body, which ensures the formation of state policy in the family and children and the corresponding structural units of all levels;

authorized subdivisions of the National Police;

child-reception centers for children of the National Police;

schools of social rehabilitation and vocational schools of social rehabilitation of educational institutions;

centers of medical and social rehabilitation of children of health care institutions;

(C) Dolzhenkov Oleksandr, Pluhatar Tetiana, 2020

DOI (Article): https: //doi.org/10.36486/np.2020.1(4.7).30

Issue 1(4.7) 2020

http://naukaipravoohorona.com/ 
special educational institutions of the State Criminal Execution Service of Ukraine;

shelters for children;

centers of social and psychological rehabilitation of children;

social rehabilitation centers (children's towns).

Other bodies of executive power, bodies of local self-government, enterprises, institutions and organizations, regardless the form of ownership, individual citizens (Article 1 of the above mentioned Law) participate in the implementation of social protection and prevention of offenses among children within their competence.

It should be noted that in this list there are no educational establishments other than schools and vocational schools of social rehabilitation of educational institutions.

According to Art. 3 of the above-mentioned Law, "for the prevention of offenses among children should be understood as the activities of children's bodies and services, special institutions for children, aimed at identifying and eliminating the causes and conditions conducive to the commission of children by offenses, as well as the positive impact on the behavior of certain children in the territory of Ukraine, in its separate region, in family, at enterprises, institutions or organizations, regardless the forms of ownership, at the place of residence".

Taking into account the foregoing, we believe that educational institutions of all types should be included into the list of subjects for the prevention of offenses among children, because they are: institutions that play a priority role in the upbringing of the child (in the family) and this is the responsibility of the pedagogical staff of the educational institutions; institutions where the child spends most of his time, therefore, the teachers have more possibilities for an identification of the causes and conditions that contribute to the child's perpetration of violence; an institution where the socialization of the child and its formation as a person are to a large extent.

Speaking about such special establishments for children as social rehabilitation schools and vocational schools of social rehabilitation of educational institutions, it should be mentioned that in 2015-2016 juvenile children were never involved into any form of forced education, i.e. children weren't sent to the above mentioned institutions.

It should be noted that in Ukraine in 2016 there were two schools and two vocational schools of social rehabilitation, in which correspondingly there were 7 and 16 children. In 2017 there were one school and one vocational school of social rehabilitation - the Komyshuvaska School in Zaporizhia Region for children aged 11-14 and the Makiyivka Vocational School of Social Rehabilitation in the Donetsk Region for children elder than 14 years. In August 2017, Okhtyrska School for Girls in Sumy Region was reorganized and joined to the State Educational Institution "Okhtyr Center for Vocational Education", which indicates the actual unclaimedness of such institutions.

In our view, this link of educational institutions requires the reformation or refusal from them with the introduction of several amendments to the Law of Ukraine "On Bodies and Services for Children and Special Institutions for Children" on their exclusion from the list of institutions that are responsible for the implementation of social protection of children and prevention among them the offenses.

DOI (Article): https: //doi.org/10.36486/np.2020.1(4.7).30

(C) Dolzhenkov Oleksandr, Pluhatar Tetiana, 2020 
We consider it to be expedient to include probation bodies into the list of subjects for the prevention of offenses among children, since "the purpose of probation is to ensure the safety of society through the correction of convicts, preventing them from committing repeated criminal offenses..." (Article 4 of the Law of Ukraine "On Probation" [2]). In addition, there are grounds for expanding the circle of persons for whom probation is carried out by including minors who are exempted from punishment with the use of coercive measures of an educational nature. Such a decision follows from the aforementioned Law, according to which the probation applies to convicted persons to perform certain types of criminal penalties, which are not related to deprivation of liberty (Article 6, Clause 2).

To create a comprehensive justice system capable of effectively preventing juvenile delinquency and providing rehabilitation of juvenile offenders, it is necessary to ensure the proper coordination of the work of all authorities authorized in the field of juvenile delinquency prevention and justice. In order to achieve such a result, a decision was made on the need for an evaluation of the existing system for the prevention of juvenile delinquency by analyzing existing programs and projects in the relevant field.

In accordance with sub-item 1 of Clause 3 of the Regulation on the Interdepartmental Coordination Council on Juvenile Justice (hereinafter - the Interdepartmental Coordination Council), approved by the Resolution of the Cabinet of Ministers of Ukraine dated May 24, 2017 No 357 [3], this body, which included representatives of ministries, the Commissioner of the President of Ukraine on the Rights of the Child, the Commissioner of the Verkhovna Rada of Ukraine on Human Rights, the General Prosecutor's Office of Ukraine, the National Police of Ukraine, international organizations, public associations, scientists and experts, gathering information on policies, programs and projects in the field of crime prevention among minors.

According to experts' decision and the results of the information gathering, a "unified map" and a bank of policies, programs and projects in the field of prevention of juvenile delinquency, which are being implemented in Ukraine as central executive authorities, as well as local government bodies, local self-government bodies, international organizations, public associations, etc.

The Interdepartmental Coordination Council will work on the following tasks:

1) development and promotion of the draft Strategy for the prevention of juvenile delinquency, focusing on: primary prevention (general crime prevention), secondary prevention (work with children of risk), tertiary prevention (work with children being in conflict with law);

2) study of the need for the amendments to the Criminal Procedural Code of Ukraine aimed at introducement of a model of restorative justice for minors in the form of a program of juvenile reconciliation (mediation in the criminal process against minors), and, if it is necessary, drafting a relevant bill;

3) determination, taking into account the results of studying the experience of foreign countries, of the internal structure and the basic provisions of the draft law on juvenile justice;

4) development and promotion of an approval of probation programs for working with minors who are in the system of probation, as well as correctional, preventive

DOI (Article): https: //doi.org/10.36486/np.2020.1(48).30

(C) Dolzhenkov Oleksandr, Pluhatar Tetiana, 2020 Issue 1(4.7) 2020 http://naukaipravoohorona.com/ 
and resocialization programs for minors who are in educational colonies and pre-trial detention centers;

5) development and promotion of the adoption of subordinate legal acts, which would determine the methods, tools for an implementation and ensure the proper functioning of the penitentiary probation system for minors;

6) development and facilitation of the introduction of an assessment system for minors, which would correlate with the assessment of risks and needs, carried out at the pre-trial stage and in the probationary period, for drawing up an effective individual work plan with a child.

The implementation of these measures will create a modern system of criminal justice for minors in the country.

Legal education of children began to be focused only in early 90's of the XX century, when the law subject was introduced into the school curriculum. However, it did not give a deep knowledge of law and right, given the incompetence of most teachers who taught this subject. Most convicted juveniles (as they say) did not know that their actions had a criminal nature and weren't familiar with the legal status of minors according to their age.

For today, students receive legal knowledge learning the course of school discipline "Fundamentals of Jurisprudence". This course is important for the formation of a legal culture, the belief in the necessity of lawful conduct, the inadmissibility of encroachment upon the rights of other citizens, the ability to protect their rights and universally recognized social values, while not forgetting about their own responsibilities of a person and a citizen; awareness of the inevitability of liability for the offense.

In order to form a negative attitude towards unlawful acts among children, it is suggested to conduct additional educational activities by:

1) the use of various pedagogical forms of material presentation in the educational process, in particular, the conduct of law studies in the form of business games with distribution of roles, modelling of life situations, social processes and procedures, discussions, etc.;

2) conduction of training with the participation of employees of the judiciary, prosecutor's office, police, court, etc., with the possibility of attending the courtroom, special institutions for minors;

3) demonstration of interviewing juvenile convicts; children who have used drugs, drank alcohol, etc. (videos from hospitals where the abovementioned persons and special institutions are located);

4. Lacks in family upbringing are the main source of formation of changes in the personality of the adolescent and determine criminal behavior.

The great propensity for anti-social, illegal, violent behavior is found in children who lived in families with authoritarian, immoral or antisocial education methods; families in difficult living conditions; incomplete and conflicting families; as well as those with special problems (for example, where there are family members who have previously served their sentence or are the members of religious denominations with specific rituals, which can cause harm to both the physical and mental health of the child); families with different levels of material wealth (as a rule, wealth or poverty); in families with parents abroad (as a result, children are social orphans, deprived of

DOI (Article): https: //doi.org/10.36486/np.2020.1(47).30

(C) Dolzhenkov Oleksandr, Pluhatar Tetiana, 2020 
an attention and control), and so on. Children deprived of parental control, in most cases resort to destructive behavior, spend more time on alcohol, drugs, gaming, hooliganism, etc.

In criminological theory it is noted that the prevention of family disadvantage should be carried out in the following sequence: the identification of dysfunctional families; diagnosis of family discomfort; carrying out of preventive measures for the normalization of the microclimate in the family; the use of administrative and criminal legal measures of influence on parents who dodge or maliciously fail to perform duties for the upbringing of children.

In order to prevent neglect, homelessness of children, which in the majority of cases leads to the destructive behavior of the latter ones, as well as the involvement of minors in anti-social activities, juvenile delinquency officers, in conjunction with the service of district police officers, the children's service and the public, must first of all identify families in a timely manner, who were in difficult living conditions, and in co-operation with other subjects for the prevention of offenses, as well as social protection agencies for children and social work to take appropriate measures to this category of families. In case of detection of signs of an offense provided for in Art. 184 KUpAP, juvenile delinquency staff shall draw up a report on the mentioned administrative offense and, along with necessary materials, shall be sent to the court. In addition, the organization of leisure and assistance in the employment of minors, as it was mentioned earlier, may contribute to solving the problem of neglect of children and, accordingly, to prevent their involvement in anti-social activities.

It should be borne in mind that there are families that are not officially classified in families that are in difficult living conditions, and that are considered to be prosperous from the outside but which have certain problems that adversely affect the children they are raised in. Due to the fact that the majority of juvenile offenders are students, the main subjects of detection of preventive activities with children and parents in such families should be a class teacher and a school policeman (if it is enshrined in this institution).

A positive step towards the prevention of domestic violence is the adoption of the Law of Ukraine "On Prevention and Combating Domestic Violence" of 07.12.2017 [4]. The novel of this act is the introduction of the institution of "a patronage over children". The possibility of "placing a child in the family of a patron teacher in the event of the child's inability to live with parents, or other legal representatives in connection with the commission of domestic violence against this child or with his participation" (Article 7, Article 9 of the Law of Ukraine "On Preventing and Combating Domestic Violence"). Such an event as a special educational effect should be in the case when the child is difficult, neglected or there is a significant threat, as it is foreseen in the Criminal Code of Switzerland (Article 82). In our opinion, it would be advisable to use it and to expand the concept of patronage over a child, as it is enshrined in Clause 1, Article 252 of the Family Code of Ukraine and to consider it as a measure of an educational influence as well.

At the same time, an important negative factor is the risk of an influence on the victim of the offender, therefore, a mechanism is needed that would make it impossible for the victim of domestic violence to apply for closure of the case at his request.

DOI (Article): https: //doi.org/10.36486/np.2020.1(47).30

(C) Dolzhenkov Oleksandr, Pluhatar Tetiana, 2020 
In order to combat effectively disadvantage and domestic violence, the main causes of juvenile delinquency are:

- to increase the efficiency of activities of all subjects of the state system of social and legal protection of children in solving the problems of the prevention of homelessness and juvenile delinquency;

- taking into account the acuteness and urgency of the problem of social orphanhood among children related to the mass exoduses of parents beyond Ukraine and their long absence, to establish the registration of such children, to improve forms and methods of establishing public custody of them;

- to strengthen information and consultative work with families regarding the prevention of homelessness and neglect of minors, the involvement of minors in antisocial or criminal activity;

- to carry out checks on the organization of work on the prevention of domestic violence in educational institutions of all types;

- to expand the concept of "patronage over a child" and consider it as means of an educational influence;

- to create a mechanism that would make it impossible for the victim of domestic violence to sue for the closure of the case at his request and thus reduce the risk of exposure to the victim.

5. There are frequent, for today, cases of violence in educational institutions. Activities for the fight this phenomenon should be pursued in two directions: prevention of violence both of teachers and students.

The legal basis for the protection of children from violence by the teaching staff is the Order of the Ministry of Education and Science of Ukraine "On Taking Additional Measures to Prevent and Combat the Ill-Treatment of Children" of 25.12.2006, No 844, which stipulates that the ill-treatment of children at school by teachers, educators concerning children is, as it follows: humiliation, setting in a corner; beating; public undressing of a kid as a method of punishment; public mentioning of the disadvantages of a kid, the peculiarities of his family, family events, which the teacher found out; unsustainable labor; ignorance of the physical needs of the child (prohibition to go to the toilet); "favorites" and "pariahs"; "high" tone, screaming, unreasonable, inadequate estimation; strict discipline based ratheron fear but not on an interest in learning; authoritarianism, requirements without explanation; inappropriate requirements to the appearance of the child (hairstyle, uniform) and the use of unlawful actions to improve it - self-cutting, removal of decorations, mobile phones, etc.; rape of minors.

There are frequent cases of degrading children's dignity by teachers. Often, confidential information about the problems of the child and his family is populated and becomes the subject of discussion in the classroom, among parents, who injure the psyche, worsens the moral condition of the child. The means of psychological pressure of separate teachers was the depreciation of educational achievements of students. Often, 11-12 scores can be obtained only by the student who has additional (paid) classes. The aforementioned, as well as professional solidarity, the false interpretation of the "protection of the honor of the uniform" form the idea of the existence of double standards in human relations.

(C) Dolzhenkov Oleksandr, Pluhatar Tetiana, 2020

DOI (Article): https: //doi.org/10.36486/np.2020.1(4.7).30 
Currently there is no proper legal regulation of cases regarding the conflict between a teacher and a student. There is a need to foresee a procedure for solving such conflicts in the Model Statute of a comprehensive educational institution, as well as disciplinary measures for teachers, pupils and their parents for failure to fulfill their duties or violations of the rights of other participants in the educational process. In particular, in Spain and the United States, such disciplinary action as school arrest is widely applied to students.

In many countries, violence among students is becoming more widespread. Instead, they do not always fall into the attention of teachers because of their high latency. There is a need to introduce an effective mechanism for reporting such facts in general education institutions. These can be tests, regular surveys, etc.

To counteract the violence among students, which takes place throughout the world, it is advisable to take advantage of the positive experience of other countries. For example, in Norway, Austria, Finland, the USA, Germany and other countries the educational-preventive program of prevention of slighting by D. Olveus is widely used. The program contains a set of information-consulting, diagnostic, organizational activities that cover all the participants in school process. Its implementation is carried out at general, group and individual levels. The program provides for the implementation of preventive measures aimed at the prevention of the spread of criminogenic phenomena and the development of typical forms of criminal activity. It was found for the pupils of 4-7 grades, and is quite effective, since during its implementation there is a decrease of the level of violence from $30 \%$ to $70 \%$.

In French schools, in addition to mandatory official reports on various manifestations of violence, which they must pass on the authority, educational institutions serve as permanent laboratories for questioning of socio-psychological direction. They are under constant supervision of various public government and nongovernmental organizations, the media.

On the basis of the above mentioned, we offer:

- to provide in the Model Statute of a comprehensive educational institution the procedure for resolving conflicts among pupils, between pupils and teachers, as well as disciplinary measures of students, their parents, teachers for failure to fulfill their duties or violation of the rights of other participants in the educational process;

- to introduce into a comprehensive educational institution a multi-level educational and preventive program for the prevention of slighting by D. Olveus;

- to provide regular monitoring of violence in schools through a regular questionnaire on socio-psychological orientation, study of the materials of "trust boxes" under the supervision of public, governmental and non-governmental organizations.

Recently, the Law of Ukraine "On Amendments to Certain Legislative Acts of Ukraine on Combating Bullying" [5], which defined the concept of bullying and provided for an administrative liability for such actions. The regulations of the law require serious reflection and evaluation on the results of their practical application.

10. High criminogenicity of children and youth is not only a feature of our state, it is a tendency that characterizes the modern world at whole. In the United Kingdom, Canada, Lithuania, Norway, Germany, Poland, the United States and other countries,

DOI (Article): https: //doi.org/10.36486/np.2020.1(47).30

(C) Dolzhenkov Oleksandr, Pluhatar Tetiana, 2020 Issue I(4.7) 2020 http://naukaipravoohorona.com/ 
preventive programs of long-term intervention are widespread to reduce juvenile delinquency. Such programs for the correction and prevention of juvenile delinquency accumulate the activities of state bodies, non-governmental organizations, volunteer groups, teachers, parents' communities and individuals, aimed at the development of socially useful skills in adolescent age groups; elimination of the causes and conditions that determine socially inappropriate behavior of the child, and prevention of the commission of a crime at various stages of socialization of the child. Early intervention prophylaxis programs are aimed at prevention of the emergence of criminogenic phenomena in the process of forming a socially acceptable space for the development of the child. In addition, at this stage of prevention, great importance is given to the formation and teaching of children with necessary skills and assistance in solving of vital problems.

An implementation of the positive international experience in juvenile delinquency prevention is an important tool for the improvement of its effectiveness in Ukraine. We suggest joining the following programs that are successfully implemented in many countries throughout the world:

School program "Quick Course". The purpose of program measures is to prevent negative deviations in the behavior of pupils of 1-6 grades, formed at home, in school and peers. Intervention prevention focuses on the most closely related to the juvenile socialization agents (family, school, permitting sphere), which form his behavior, the attitude to social norms and the ability to adhere to them. This program has become widespread in the UK, Australia, Canada, and the United States.

A program to restrict the leisure of juveniles committing offenses or crimes. Such measures are implemented by special institutions and schools, where individuals who have committed an offense, a crime or have asocial manifestations in their behavior, spend time free from education. In addition, the educational process involves minors' parents with socially inappropriate behavior. The program is used in Ireland.

The Youth Employment Assistance Program covers young people aged 15-18 who are registered in the juvenile correction system. The main objective of the program is to provide support in education, professional skills and employment used in Ireland.

Drug-based program is based on the motivation model of decision-making skills. It was developed as a classroom program for the prevention of drug abuse by minors (elder than 14 years), pupils of correctional and alternative schools. The main objectives of the program are: to reduce or to eliminate completely the use of tobacco, alcohol, marijuana and heavy drugs; reduction or complete elimination of weapons; increasement of the demonstration of behavioral and cognitive self-control skills for students. It is widespread in Ireland.

Educational and preventive program "Training to Resist the Criminal Group Success". It is a continuation of the program "Learning to Confront Drug Addiction - Try it" and aims at forming a sense of justice of minors, in particular, difficult children, under the guidance of teachers. Graduating students receive certificates. Students who have successfully completed the training on the above mentioned programs continue to teach others through the "peer-to-peer" method. The program is used in 50 countries throughout the world, in particular, in Canada, Germany, Cuba, Mexico, Spain, Turkey, etc.

DOI (Article): https: //doi.org/10.36486/np.2020.1(47).30

(C) Dolzhenkov Oleksandr, Pluhatar Tetiana, 2020 
Consequently, in development of a system of program measures for the correction and prevention of juvenile delinquency in Ukraine, foreign positive experience regarding the adaptability of various components of long-term and early intervention programs for persons of different age groups should be taken into account, as well as the possibility of their application to children. It is necessary to provide an integrated approach to coordination of the activities of social institutions (especially in the family and the sphere of education) with the support of local authorities, local selfgovernment bodies, law enforcement and public health authorities, and the public.

\section{REFERENCES}

1. On Bodies and Services for Children and Special Establishments for Children: Law of Ukraine dated January 24, 1995. No 20/95-VR. URL: http://zakon3.rada.gov.ua/laws/show (Date of Application: 12.02.2020) [in Ukrainian].

2. On Probation: Law of Ukraine. Bulletin of Verkhovna Rada of Ukraine. 2015. No 13. Art. 93. URL: https://xn-80aagahqwyibe8an.com/zakon-ukrajiny/stattya-sfera-diji-60006.html (Date of Application: 21.02.2020) [in Ukrainian].

3. On the Establishment of Interrelation Coordination for the Juvenile Law: Resolution of the Cabinet of Ministers of Russia dated 24.05.2017 No 357. URL: http://zakon3.rada.gov.ua/laws/ show/357-2017-\%D0\%BF (Date of Application: 21.02.2020) [in Ukrainian].

4. On Preventing and Combating Domestic Violence: Law of Ukraine dated 07.12.2017 No 2229-VIII. URL: http://zakon2.rada.gov.ua/laws/show/2229-19 (Date of Application: 21.02.2020) [in Ukrainian].

5. On Amendments to Certain Legislative Acts of Ukraine on Combating Bullying (Hunt): Law of Ukraine dated 18.12.2018 No 2657-VIII. URL: https://zakon.rada.gov.ua/laws/show/265719 (Date of Application: 04.02.2020) [in Ukrainian].

УДК 343.91-053.6

Долженков Олександр Федорович, доктор юридичних наук, професор, професор Південноукраїнського національного педагогічного університету імені К.Д. Ушинського,

м. Одеса, Україна

Плугатар Тетяна Анатоліївна, кандидат юридичних наук, старший науковий співробітник, учений секретар секретаріату Вченої ради ДНДІ МВС України, м. Київ, Україна,

ORCID ID 0000-0003-2082-5790

\section{СПЕЦІАЛЬНО-КРИМІНОЛОГІЧНІ ЗАХОДИ ЗАПОБІГАННЯ ЗЛОЧИНАМ НЕПОВНОЛІТНІХ В УКРАЇНІ}

Стаття присвячена висвітленню діяльності державних органів, громадських організацій та громадян щодо запобігання злочинності неповнолітніх, яка спрямована на усунення, ослаблення, нейтралізацію негативного впливу та виникнення протиправної поведінки неповнолітніх. Наголошено, що крім загальних заходів запобігання злочинів неповнолітніх, таких як культурно-виховна

DOI (Article): https: //doi.org/10.36486/np.2020.1(4.7).30

(C) Dolzhenkov Oleksandr, Pluhatar Tetiana, 2020 Issue 1(4.7) 2020

http://naukaipravoohorona.com/ 
робота, підвищення морально-культурного рівня сім'ї, а також спілкування у школах, зниження пропаганди насильства у 3MI, на особливу увагу заслуговують спеціально-кримінологічні й індивідуальні заходи запобігання злочинам, що вчиняються неповнолітніми.

У розвинених країнах досить успішно реалізуються програми попередження соціальної дезадаптації і злочинності серед дітей і молоді, які передбачають систему комплексних заходів, спрямованих на запобігання соціально неприйнятному розвитку дитини. При цьому увагу зосереджено на: належних умовах життя дитини; регулярності процесів освіти і виховання дитини; дотриманні прав дітей, забезпеченні дітям почуття безпеки, прийнятті та розширенні прав і можливостей дітей; активній участі дітей у культурному житті і створенні можливостей для належного управління дозвіллям; розвитку соціального забезпечення, допомозі дітям і сім’ям, які перебувають у складному фінансовому становищі; заходах безпеки та громадському порядку. Дітям забезпечено широкі межі свободи, а головною умовою є неприпустимість порушення прав, свобод інших людей.

Наголошується, що при формуванні системи програмних заходів корекції й запобігання злочинам неповнолітніх в Україні слід враховувати зарубіжний позитивний досвід щодо адаптованості різноманітних компонентів програм тривалого та раннього втручання до осіб різних вікових груп, а також наявність можливості їх застосування до дітей. Необхідно забезпечити комплексний підхід до координації діяльності соціальних інститутів суспільства (особливо у сфері сім’ї та освіти) за підтримки місцевих органів виконавчої влади, органів місцевого самоврядування, органів охорони правопорядку та охорони здоров’я, громадськості.

Ключові слова: насильство серед учнів, фізичне насильство, психічне насильство, кримінологічна характеристика, запобігання, спеціально-кримінологічні заходи, злочини, що вчиняються неповнолітніми.

Отримано 18.02.2020

DOI (Article): https: //doi.org/10.36486/np.2020.1(47).30

Dolzhenkov Oleksandr, Pluhatar Tetiana, 2020 